\title{
STANDARDISASI EKSTRAK PEGAGAN, CENTELLA ASIATICA SEBAGAI OBAT HERBAL TERSTANDAR HEPATOPROTEKTOR
}

\author{
STANDARDIZATION OF PEGAGAN EXTRACT, CENTELLA ASIATICA AS \\ HEPATOPROTECTIVEHERBAL MEDICINE
}

\author{
Puspa Dewi N Lotulung1), Sri Handayani' ${ }^{2}$, Teni Ernawati ${ }^{1)}$, Tri Yuliani ${ }^{1)}$, \\ Nina Artanti ${ }^{1)}$ dan Tjandrawati Mozef ${ }^{2)}$ \\ ${ }^{1)}$ Pusat Penelitian Kimia-LIPI, Kawasan Puspiptek Serpong, Tangerang Selatan 15314 \\ ${ }^{2)}$ Pusat Penelitian Kimia-LIPI, Jl. Cisitu-Sangkuriang Bandung 40135 \\ Email : puspade@yahoo.com
}

Diterima : 10 Agustus 2015, Revisi : 11 September 2015, Disetujui : 13 Nopember 2015

\begin{abstract}
ABSTRAK
Produk obat herbal/produk jamu yang berasal dari tanamanakan dipengaruhi dari kualitas bahan baku. Kualitas bahan baku tanaman juga akan dipengaruhi berbagai faktor; baik itu kondisi tanah, budidaya, pasca panen maupun pada saat pengolahan bahan baku menjadi simplisia ataupun ekstrak. Oleh karena itu, untuk membuat obat herbal diperlukan standarisasi ekstrak agar dihasilkan obat herbal yang memiliki kualitas dan fungsi efektivitas yang sama dalam setiap prosesnya.Dari studi pendahuluan yang telah dilakukan, Centella asiatica merupakan salah satu tanaman potensialsebagai sumber senyawa hepatoprotektor.Uji in vivo dan in vitro terhadap ekstrak tanaman pegagan telah menunjukkan hasil yang sangat baik. Ekstrak etil asetat $17,5 \mathrm{mg} / \mathrm{kg} \mathrm{BB}$ dan butanol $228,8 \mathrm{mg} / \mathrm{kg}$ BB pegagan dibuktikan mempunyai efek hepatoprotektor pada uji in vivo menggunakan mencit yang diinduksi oleh $\mathrm{CCl}_{4}$. Ekstrak etil asetat mampu menurunkan kadar enzim alanine aminotransferase (ALT) dan aspartate aminotransferase (AST) sebesar 56\% dan $44 \%$ berturut-turut, sementara ekstrak butanol mampu menurunkan kadar enzim AST sebesar 3\%. Standarisasi ekstrak pegagan yang dilakukan di dalam penelitian ini adalah karakterisasi ekstrak berupa parameter non spesifik dan spesifiksesuai acuan dari PPOMN (Depkes RI, 2000) meliputi; kadar susut pengeringan, kadar abu, cemaran mikroba angka lempeng total, kadar senyawa yang larut dalam air, kadar senyawa yang larut dalam etanol, uji fitokimia, kadar total fenolik, kadar total flavonoid dan penentuan logam berat $\mathrm{Pb}$ dan Cd.Hasil penelitian menunjukkan bahwa parameter non spesifik untuk ekstrak etanol pegagan telah memenuhi persyaratan Farmakope Herbal tahun 2008 yang meliputi; penentuan kadar susut pengeringan $\leq 10 \%$, kadar abu $\leq 16.6 \%$ dan cemaran mikroba negatif. Demikian pula untuk
\end{abstract}

parameter spesifik yang dilakukan untuk ekstrak etanol pegagan, telah memenuhi persyaratan Farmakope Herbal tahun 2008.

Kata Kunci: Centella asiatica, pegagan, hepatoprotektor, obat herbal terstandar, parameter spesifik dan parameter non spesifik

\section{ABSTRACT}

Herbal medicinal products would be affected by the quality of raw materials. In turn, the quality of raw material will also be influenced by various factors such as soil conditions, cultivation, post-harvest processing, and the processing of raw materials into crude drug or extract. Therefore, in order to make good herbal medicines, it is necessary to make standardization of herbal extracts that produced herbal medicines that have the same quality and functions of effectiveness in each process. From preliminary studies that have been done, Centella asiatica is one of the potential plants as a source of hepatoprotective compounds. Test in vivo and in vitro against Centella asiatica extracts have shown very good results. Ethyl acetate extract with $17.5 \mathrm{mg} / \mathrm{kg}$ of doses body weight and butanol $228.8 \mathrm{mg} / \mathrm{kgof}$ doses body weight has been applied for in vivo test using mice induced by $\mathrm{CCl}_{4}$; theydemonstrated hepatoprotective effects. Ethyl acetate extracts were able to reduce levels of the enzyme alanine aminotransferase (ALT) and aspartate aminotransferase (AST) by $56 \%$ and $44 \%$ respectively while butanol extract can reduce the enzymes AST levels by 3\%. Standardizationof Centella asiatica extract performed in this study was the characterization of the extract in the form of non-specific and specific parameters corresponding to the reference of PPOMN 
(Ministry of health Republic of Indonesia, 2000) such as levels of drying shrinkage, ash content, total plate count microbial contamination, levels of water-soluble compounds, levels of compounds that are soluble in ethanol, phytochemical test, total phenolic content, total flavonoid content and the determination of $\mathrm{Pb}$ and $\mathrm{Cd}$ weight.The results showed that non-specific parameters for the ethanol extract of Centella asiatica were requirements based on Herbal Pharmacopoeia in 2008 which includes parameters such as determination of shrinkage on drying $\leq 10 \%$, ash content $\leq 16.6 \%$ and negative microbial contamination. Specific parameters for the ethanol extract of Centella asiatica have met the requirements of Herbal pharmacopeia in 2008.

Keywords: Centellaasiatica, hepatoprotective, standardized herbal medicine, specificparameters, and non-specific parameters

\section{PENDAHULUAN}

Hingga saat ini hepatitis virus A, B dan $\mathrm{C}$ masih menjadi masalah kesehatan dunia karena berpotensi menimbulkan dampak morbiditas dan mortalitas. Hepatitis yang ditandai oleh kerusakan pada sel-sel hati disebabkan karena peradangan jaringan hati karena infeksi atau non infeksi. Hepatitis yang disebabkan karena infeksi biasanya terjadi karena virus, terutama virus hepatitis A, B, C, D, dan E. Berdasarkan data Riset Kesehatan Dasar yang dilakukan oleh Kementerian Kesehatan pada tahun 2007 diketahui bahwa prevalensi HBsAg di Indonesia sebesar $9,7 \%$ pada pria dan $9,3 \%$ pada wanita, dengan angka tertinggi pada kelompok usia 45-49 tahun sebesar 11,9\%. Sementara prevalensi penderita hepatitis C sebesar 0,8\%, dengan angka tertinggi pada kelompok usia 55-59 tahun, yaitu sebesar 2,12\%. Hepatitis B, C, D dapat menimbulkan keadaan infeksi yang menetap yang akan menjadi hepatitis kronis, sirosis, dan kanker hati.Kerusakan hati juga dapat diakibatkan oleh alkohol, obat-obatan (asetaminofen, allopurinol, parasetamol, eritromisin dll), bahan beracun (ec. Amanita phalloides) serta penyakit autoimun ${ }^{1}$.

Penyakit hepatitis banyak terdapat di negara berkembang, namun teknologi dan fasilitas pencegahan serta pengobatan lebih banyak dimiliki oleh negara maju yang justru bukan merupakan daerah endemis hepatitis B. Akibatnya biaya pengobatan penyakit hepatitis masih merupakan beban yang besar bagi masyarakat di negara berkembang. Oleh sebab itu upaya yang didorong oleh pemerintah adalah upaya pencegahan.

Hepatoprotektor adalah suatu senyawa obat yang dapat memberikan perlindungan pada hati dari kerusakan yang ditimbulkan oleh racun, obat, dan lain-lain. Untuk mengetahui apakah terjadi kerusakan hati biasanya dilakukan serangkaian pemeriksaan kandungan senyawa-senyawa dalam tubuh sperti kadar SGOT (Serum Glutamic Oxaloacetic transaminase), SGPT (Serum Glutamic Piruvic Transaminase), atau pemeriksaan imunokimia (bila diduga disebabkan oleh virus) dan pemeriksaan lainnya.SGPT atau AST (Aspartat Transaminase) dan SGOT atau ALT (Alanin Transaminase), keduanya merupakan enzim intraseluler yang dalam keadaan normal berada didalam $\mathrm{sel}^{2}$. Keduanya merupakan enzim transaminase yang berfungsi mengkatalisis reaksi kimia yang terjadi dalam sel.Ketika terjadi serangan pada sel hati oleh senyawa obat yang toksik terhadap hati, mikroorganisme, dll, maka akan terjadi perubahan permeabilitas pada membran sel sehingga enzim-enzim yang seharusnya berada didalam sel akhirnya melarikan diri keluar sel dan berada dalam darah sehingga disebut transminase serum karena enzim tersebut terdeteksi berada didalam serum. Kadar SGOT normal berkisar antara 5-40 unit/L serum sementara kadar SGPT normal berkisar antara 7-56 unit/L serum.SGOT atau AST tidak hanya berada di hati, enzim ini juga terdapat dalam organ lainnya seperti jantung, otot, ginjal, dan otak. Sehingga, terjadinya kenaikan 
kadar ini tidak serta merta menjadi landasan bahwa seseorang mengalami kerusakan hati. Karena bisa saja jantung, ginjal, atau otot yang mengalami kerusakan. Sementara SGPT atau AST berada di hati, sehingga pemeriksaan ini lebih valid untuk merujuk pada kerusakan hati.Disinilah peranan senyawa-senyawa yang bersifat hepatoprotektor. Senyawa tersebut diberikan dengan harapan kadar SGPT dan SGOT dapat berkurang dengan signifikan ${ }^{(3)}$. Berkurangnya kadar kedua parameter tesebut menandakan bahwa sel yang mengalami kerusakan tidak bertambah, karena semakin banyak sel yang mengalami kerusakan maka kadar SGPT akan terdeteksi makin tinggi. Kerusakan yang terjadi pada sel-sel hati itu biasanya karena reaksi oksidasi, sehingga beberapa obat yang dirujuk sebagai hepetoprotektor biasanya merupakan antioksidan. Salah satu contohnya adalah silimarin yang merupakan senyawa yang terkandung dalam tumbuhan Sylibummarianum. Silimarin merupakan campuran flavonolignan, yang mengandung silibin(senyawa utama), isosilibin, silidianin, dan silikristin ${ }^{1,2,4}$.

Melalui kerjasama riset antara LIPI dengan Zhejiang University, China dalam hal pengembangan tanaman obat Indonesia, telah terseleksi tanaman pegagan Centella asiatica sebagai sumber senyawa hepatoprotektor. Uji in vivo dan in vitro terhadap ekstrak tanaman tersebut telah menunjukkan hasil yang sangat baik. Ekstrak etil asetat $17,5 \mathrm{mg} / \mathrm{kg}$ BB dan butanol 228,8 $\mathrm{mg} / \mathrm{kg} \quad \mathrm{BB}$ pegagan dibuktikan mempunyai efek hepatoprotektor pada uji in vivo menggunakan mencit yang diinduksi oleh $\mathrm{CCl}_{4}$. Ekstrak etil asetat mampu menurunkan kadar enzim alanine aminotransferase (ALT) dan aspartate aminotransferase (AST) sebesar 56\% dan $44 \%$ berturut-turut, sementara ekstrak butanol mampu menurunkan kadar enzim AST sebesar 3\%. Pemeriksaan histopatologi organ hati yang diberi perlakuan $\mathrm{CCl}_{4}$ menunjukkan bahwa penambahan ekstrak etil asetat dan butanol pegagan menunjukkan efek hepatoprotektor dimana tidak tampak adanya nekrosis dan pembentukan vakuola.Studi toksisitas akut terhadap ekstrak etil asetat dan butanol pegagan pada mencit menunjukkan bahwa hingga dosis $5 \mathrm{~g} / \mathrm{kg}$ BB tidak tampak gejala toksisitas pada hewan uji ${ }^{5-9}$.

Hasil tersebut menunjukkan bahwa tanaman pegagan berpotensi untuk dikembangkan sebagai obat herbal terstandar hepatoprotektor.Standardisasi ekstrak pegagan yang dilakukan di dalam penelitian ini adalah karakterisasi ekstrak berupa parameter non spesifik dan spesifik sesuai acuan dari PPOMN (Depkes RI, 2000) meliputi; kadar susut pengeringan, kadar abu, cemaran mikroba angka lempeng total, kadar senyawa yang larut dalam air, kadar senyawa yang larut dalam etanol, uji fitokimia, kadar total fenolik, kadar total flavonoid dan penentuan logam berat $\mathrm{Pb}$ dan $\mathrm{Cd}^{10,11,12,14}$.

\section{BAHAN DAN METODE}

\section{Bahan}

Herba pegagan dikumpulkan dari daerah Bandung. Pelarut yang digunakan adalah pelarut etanol teknis yang didestilasi. Untuk pemurnian ekstrak digunakan silika gel (E.Merck) dan untuk mengecek bercak/spot ekstrak digunakan kromatografi lapis tipis berderajat pro analisa silika gel $\mathrm{GF}_{254}$ (E. Merck). Mikroba, quercetin, senyawa flavonoid, standar $\mathrm{Pb}$, standar $\mathrm{Cd}, \mathrm{CCl}_{4}$, mencit, enzim AST, enzim ALT

\section{Peralatan}

Lampu UV CAMAG, neraca analitik, spektrophotometer UV shimadzu, inkubator, evaporator, homogenizer, 
Laminar Air Flow, alat gelas untuk kebutuhan penelitian.

\section{Metode}

\section{Penyiapan Ekstrak Pegagan}

Ekstraksi $5 \mathrm{~kg}$ simplisia pegagan dengan etanol 70\%. Ekstrak ini yang digunakan untuk karakterisasi ekstrak dan untuk penentuan aktivitas ekstrak. Hal ini dikarenakan ekstrak yang nantinya digunakan untuk formulasi sediaan yang diperbolehkan oleh PPOMN-BPOM RI adalah ekstrak etanol.

\section{Pengujian Aktivitas Hepatoprotektor ${ }^{15,16}$}

Menggunakan enam kelompok dan tiap kelompok terdiri dari tiga ekor mencit. Kelompok ertama diberikan standar, kedua dan ketiga diberikan ekstrak etil asetat pegagan dan ekstrak butanol pegagan berturut-turut. Hewan uji coba diberi sediaan selama tujuh hari berturut-turut dan pada hari kedelapan diberi $\mathrm{CCl}_{4} \quad 0,1$ $\mathrm{mL} / \mathrm{kg} \mathrm{BB}$ dan pada hari kesembilan dilakukan pengambilan sampel darah yang diikuti dengan pengambilan organ hati. Aktivitas hepatoprotektor tertinggi dinilai dari kadar enzim alanin transaminase dan aspartat transaminase.

\section{Pengujian biokimi fungsi hati ${ }^{15,16}$}

Sampel darah diambil dari jantung, sampel ini kemudian disentrifus dengan kecepatan 2500 rpm selama 10-15 menit, kemudian serum dipisahkan dan dimasukkan ke dalam ependorf. Selanjutnya dilakukan pengukuran kadar enzim alanin transaminase dan aspartat transaminase.

\section{Kadar senyawa yang larut dalam air ${ }^{11}$}

Maserasi sejumlah 5.0 gram ekstrak selama 24 jam dengan $100 \mathrm{~mL}$ air kloroform LP ( $2,5 \mathrm{~mL} \mathrm{CHCl}_{3}$ addkan hingga menjadi $1000 \mathrm{~mL}$ dengan aquadest, LP = Larutan Pereaksi) menggunakan labu bersumbat sambil berkali-kali dikocok selama 6 jam dan kemudian dibiarkan selama 18 jam. Saring, uapkan $20 \mathrm{~mL}$ filtrat hingga kering dalam cawan dangkal berdasar rata yang telah ditara, panaskan residu pada suhu $105{ }^{\circ} \mathrm{C}$ hingga bobot tetap. Hitung kadar dalam persen senyawa yang larut dalam air, dihitung terhadap ekstrak awal.

\section{Kadar senyawa yang larut dalam etanol ${ }^{14}$}

Maserasi sejumlah 5.0 gram ekstrak selama 24 jam dengan $100 \mathrm{~mL}$ ethanol (95 $\%)$, menggunakan labu bersumbat sambil berkali-kali dikocok selama 6 jam dan kemudian dibiarkan selama 18 jam.Saring, uapkan $20 \mathrm{~mL}$ filtrat hingga kering dalam cawan dangkal berdasar rata yang telah ditara, panaskan residu pada suhu $105{ }^{\circ} \mathrm{C}$ hingga bobot tetap. Hitung kadar dalam persen senyawa yang larut dalam ethanol (95\%), dihitung terhadap ekstrak awal.

\section{Cemaran mikro ${ }^{14}$}

a. Metode Angka Lempeng Total (ALT)

1. Kapang/Fungi

0,1 gr ekstrak pegagan disuspensikan dalam $10 \mathrm{~mL}$ air tween $0,1 \%$ steril, kemudian dilakukan pengenceran $10^{-1}$ dan $10^{-2}$, diambil $1 \mathrm{ml}$ dari setiap pengenceran kemudian dihomogenkan dengan media tumbuhnya ( PDA ) sebanyak 15 $\mathrm{mL}$. Setelah beku, inkubasi dalam oven inkubator $30{ }^{\circ} \mathrm{C}$. Semua tahapan pekerjaan dilakukan secara aseptic. Pengamatan dilakukan setelah inkubasi 24 jam dan 48 jam.

2. Bakteri

0,1 gr ekstrak pegagan disuspensikan dalam $10 \mathrm{~mL} \mathrm{NaCl}$ physologis $0,95 \%$ steril, kemudian dilakukan pengenceran $10^{-1}$ dan 


\begin{abstract}
$10^{-2}$, diambil $1 \mathrm{~mL}$ dari setiap pengenceran kemudian di homogenkan dengan media tumbuhnya ( NA ) sebanyak 15 $\mathrm{mL}$.
\end{abstract}

Setelah beku, inkubasi dalam oven inkubator $37{ }^{0}$ C.Semua tahapan pekerjaan dilakukan secara aseptik.Pengamatan dilakukan setelah inkubasi 24 jam dan 48 jam.

\section{b. Uji Nilai Duga Terdekat (MPN) Coliform.}

1 gram sampel dilarutkan dalam 10 $\mathrm{mL}$ aquadest steril, dilakukan pengenceran bertingkat $10^{-1} ; 10^{-2} ; 10$ -3. Kedalam 3 tabung pertama diinokulasi $1 \mathrm{~mL}$ sampel $10^{-1} ; 3$ tabung kedua dinokulasi $1 \mathrm{~mL}$ sampel $10^{-2}$ dan 3 tabung terakhir diinokulasi $1 \mathrm{~mL}$ sampel $10^{-3}$.

\section{Uji Alkaloid $^{14}$}

Sampel + Ammonium 10\% , diekstraksi dengan $\mathrm{CHCl}_{3}+\mathrm{HCl} 1 \mathrm{~N}$.

- Larutan asam + pereaksi Dragendorf $\rightarrow$ hasil positif, larutan kuning $\rightarrow$ jingga

- Larutan asam + pereaksi Meyer $\rightarrow$ hasil positif, terbentuk endapan putih

Dari percobaan terhadap sampel ekstrak pegagan, hasil $:+$ (positif), larutan kuning $\rightarrow$ jingga dan terbentuk endapan putih.

\section{Uji Fenolik ${ }^{14}$}

Sampel $+\mathrm{FeCl}_{3} 1 \%$ (dalam air/ethanol) $\rightarrow$ hasil positif, jika terjadi perubahan warna hijau, merah ungu, biru/hitam. Dari percobaan terhadap sampel ekstrak pegagan, hasil : + (positif) warna merah ungu.

\section{Uji Flavonoid $^{14}$}

Sampel + serbuk $\mathrm{Mg}+\mathrm{HCl} 2 \mathrm{~N}$ dipanaskan $100{ }^{\circ} \mathrm{C}$ dalam water bath selama 5 - 10 menit, didinginkan, disaring, filtrat + Amil Alkohol $\rightarrow$ hasil positif, larutan merah jingga.

Dari percobaan terhadap sampel ekstrak pegagan, hasil : + (positif) larutan merah jingga.

\section{Uji Triterpenoid /steroid ${ }^{14}$}

Sampel + asam asetat anhidrat (terendam), biarkan 15 menit +2 tetes $\mathrm{H}_{2} \mathrm{SO}_{4}$ pekat.

Hasil menunjukkan larutan hijau-biru $\rightarrow$ positif Steroid.

Hasil menunjukkan larutan unggu $\rightarrow$ positif Triterpenoid.

Dari percobaan terhadap sampel ekstrak pegagan, hasil : (+) Triterpenoid,(-) Steroid.

\section{Uji Saponin $^{14}$}

Sampel + air ,dididihkan dalam penangas selama 5 menit, disaring kemudian dikocok kuat terbentuk busa stinggi $2 \mathrm{~cm}$ yang stabil selama 1 jam $+\mathrm{HCl} \mathrm{0,1} \mathrm{N}$ busa tetap $\rightarrow$ hasil positif Saponin.Dari percobaan terhadap sampel ekstrak pegagan, hasil : + (positif), busa tetap selama 1 jam dan dengan penambahan $\mathrm{HCl} 0,1 \mathrm{~N}$.

\section{Penentuan kadar Fenol ${ }^{14}$}

$100 \mu \mathrm{l}$ ekstrak $+4,5 \mathrm{~mL}$ aquadest +100 ul Folin Ciocal, dihomogenkan selama 3 menit +300 $\mu 1 \mathrm{Na}_{2} \mathrm{CO}_{3} .2 \%$ kemudian diinkubasi pada temperatur kamar selama 2 jam, diukur absorbannya pada $\lambda 760 \mathrm{~nm}$.

\section{Penentuan kadar flavonoid ${ }^{14}$}

$500 \mu \mathrm{l}$ sampel $+500 \mu \mathrm{l} \mathrm{AlCl}_{3} 2 \%$ (dalam etanol), dihomogenkan ,diinkubasi selama 1 jam ,kemudian diukur absorbannya pada $\lambda 420 \mathrm{~nm}$. 


\section{HASIL DAN PEMBAHASAN}

Hasil uji kemampuan berbagai sediaan ekstrak pegagan dalam melindungi sel sel hati dari efek hepatotoksik $\mathrm{CCl}_{4}$ menunjukkan bahwa sediaan ekstrak pegagan menunjukkan hasil ekstrak etil asetat $17,5 \mathrm{mg} / \mathrm{kg} \mathrm{BB}$ dan butanol 228,8 $\mathrm{mg} / \mathrm{kg}$ BB.Ekstrak etil asetat mampu menurunkan kadar enzim alanine aminotransferase (ALT) dan aspartate aminotransferase (AST) sebesar 56\% dan $44 \%$ berturut-turut, sementara ekstrak butanol mampu menurunkan kadar enzim AST sebesar 3\%. Pemeriksaan histopatologi organ hati yang diberi perlakuan $\mathrm{CCl}_{4}$ menunjukkan efek hepatoprotektor pada penambahan ekstrak etil asetat dan butanol pegagan, dimana tidak tampak adanya nekrosis dan pembentukan vakuola.Studi toksisitas akut terhadap ekstrak etil asetat dan butanol pegagan pada mencit menunjukkan bahwa hingga dosis $5 \mathrm{~g} / \mathrm{kg}$ BB tidak tampak gejala toksisitas pada hewan uji.

Dari berbagai penelitian telah dilaporkan bahwa $\mathrm{CCl}_{4}$ dapat menyebabkan kerusakan hati sebagaimana yang ditimbulkan oleh virus hepatitis akut, ditandai dengan peradangan akut pada sel-sel hati ${ }^{(7,8)}$. Kerusakan sel hati akan mempengaruhi enzim enzim hati, bilirubin dan protein dalam serum. Banyak dilaporkan dari penelitian penelitian sebelumnya bahwa pemberian kadar $\mathrm{CCl}_{4}$ akan meningkatkan kadar bilirubin total, enzim ALT, AST dan ALP (alkalin posfatase) serta menurunkan kadar protein total dalam serum (6). Daya proteksi suatu senyawa terhadap $\mathrm{CCl}_{4}$ dapat dilihat dari kemampuannya dalam menghambat peroksidase lipid ${ }^{(15)}$ dan dapat menekan aktivitas enzim ALT dan $\mathrm{AST}^{(16)}$. Dilihat dari uji di atas dapat dilaporkan bahwa ekstrak pegagan dapat melindungi sel-sel hati dari $\mathrm{CCl}_{4}$ dengan kemampuannya dapat menekan aktivitas enzim ALT dan AST.

Standardisasi ekstrak pegagan yang dilakukan di dalam penelitian ini adalah karakterisasi ekstrak berupa parameter non spesifik dan spesifik sesuai acuan dari PPOMN (Depkes RI, 2000) meliputi; kadar susut pengeringan, kadar abu, cemaran mikroba angka lempeng total, kadar senyawa yang larut dalam air, kadar senyawa yang larut dalam etanol, uji fitokimia, kadar total fenolik, kadar total flavonoid dan penentuan logam berat $\mathrm{Pb}$ dan $\mathrm{Cd}$. Untuk ekstrak etanol pegagan baik untuk parameter spesifik maupun parameter non spesifik telah memenuhi persyarataan Farmakope Herbal tahun 2008. Adapun data data hasil standardisasi yang telah dilakukan di dalam penelitian ini bisa di lihat dalam Tabel 2 yang terlampir di bawah ini.

Tabel 1. Kadar enzim ALT dan AST dalam serum tikus jantan Sprague Dawley yang diberi Ekstrak Centela asiatica

\begin{tabular}{ccc}
\hline \multirow{2}{*}{ Peubah } & \multicolumn{2}{c}{ Perlakuan } \\
\cline { 2 - 3 } & Ekstrak Etil Asetat & Ekstrak butanol \\
\hline Kadar Penurunan enzim ALT (alanin aminotransferase) & $56 \%$ & - \\
\hline Kadar Penurunan enzim AST (aspartate aminotransferase) & $44 \%$ & $3 \%$ \\
\hline
\end{tabular}

Tabel 2. Data karakteristik Ekstrak Parameter non spesifik

\begin{tabular}{|c|c|c|}
\hline No. & Data Karakteristik & Hasil Pengujian \\
\hline 1. & Kadar susut pengeringan & $4.430 \%$ \\
\hline 2. & Kadar abu & $2.775 \&$ \\
\hline 3. & $\begin{array}{cl}\text { Cemaran mikroba : } \\
- & \text { Angka lempeng total : kapang } \\
- & \text { Angka lempeng total : bakteri } \\
- & \text { Uji nilai duga terdekat }\end{array}$ & $\begin{array}{l}(-) \\
(-) \\
(-)\end{array}$ \\
\hline
\end{tabular}


Untuk karakteristik parameter non spesifik kadar susut pengeringan ekstrak etanol pegagan diperoleh hasil kadar rata-rata susut pengeringan sekitar $4.430 \%$ sedangkan hasil susut pengeringan yangsesuai dengan acuan Farmakope herbal (2008) yaitu $\leq 10 \%$. Jadi parameter kadar susut pengeringan untukekstrak etanol pegagan masih dalam range acuan Farmakope Herbal.Untuk karakteristik parameter non spesifik kadar abu ekstrak etanol pegagan diperoleh hasil rata-rata kadar abu sekitar $2.775 \%$ sedangkan hasil penetapan kadar abu total sesuai dengan acuan Farmakope herbal (2008) yaitu $\leq 16,6 \%$. Jadi parameter kadar abu untuk ekstrak etanol pegagan masih dalam range acuan Farmakope Herbal.

Oleh karena tidak ada satupun cawan yang menunjukan jumlah koloni 30-300 koloni, maka nilai angka lempeng total kapang, bakteri maupun uji nilai duga terdekat perkiraa nilainya diambil dari angka sebenarnya dari tingkat pengenceran terendah. Nilai rata-rata angka lepeng total perkiraan dari ekstrak etanol pegagan adalah 0,75 $\pm 1,91$ $\mathrm{CFU} / \mathrm{g}$. Nilai ini termasuk dalam batas aman sesuai acuan SNI 19-2897-1992.Menurut SNI 19-2897-1992, batas jumlah cemaran mikroba dalam ekstrak yang dipersyaratkan adalah $<10^{6}$ CFU/g. Untuk karakteristik parameter spesifik kadar senyawa yang larut dalam air ekstrak etanol pegagan diperoleh hasil rata-rata kadar senyawa yang larut dalam air sekitar $59.14 \%$ sedangkan kadar senyawa larut air ekstrak pegagan sesuai dengan acuan Farmakope herbal yaitu $\geq 28,3 \%$.Untuk karakteristik parameter spesifik kadar senyawa yang larut dalam etanol ekstrak etanol pegagan diperoleh hasil rata-rata kadar senyawa yang larut dalam etanol sekitar $17.89 \%$ sedangkan kadar senyawa senyawa yang larut dalam etanolekstrak pegagan sesuai dengan acuan Farmakope herbal yaitu $\geq 2,1 \%$.Dari hasil uji fitokimia menunjukkan bahwa ekstrak etanol pegagan positif mengandung senyawa alkaloid, fenolik, flavonoid, triterpenoid dan saponin akan tetapi ekstrak etanol pegagan tidak mengandung senyawa steroid (negatif).Secara kuantitatif kandungan total fenol dalam ekstrak sebesar $0.825 \%$ b/b sedangkan untuk kadar total flavonoid sebesar $0.556 \% \mathrm{~b} / \mathrm{b}$. Penentuan kandungan kadar logam berat, diujikan pada 2 jenis logam yaitu: $\mathrm{Pb}$ dan $\mathrm{Cd}$. Kandungan logam dalam ekstrak pegagan sebesar 1.61 ppm untuk logam $\mathrm{Pb}$ dan 0.069 ppm untuk logam Cd.Jadi parameter spesifik kadar senyawa yang larut dalam air untuk ekstrak etanol pegagan masih dalam range acuan Farmakope Herbal.

Dari semua hasil data karakteristik parameter spesifik dan non spesifik yang telah dilakukan terhadap ekstrak etanol pegagan menunjukkan bahwa ekstrak yang dibuat telah memenuhi persyaratan Farmakope Herbal tahun 2008, yang berarti ekstrak etanol pegagan yang dibuat telah memenuhi standar sebagai ekstrak terstandar.

Tabel 3.Data karakteristik Ekstrak Parameter spesifik

\begin{tabular}{|c|c|c|}
\hline No. & $\begin{array}{c}\text { Data Karakteristik } \\
\end{array}$ & Hasil Pengujian \\
\hline 1. & Kadar senyawa yang larut dalam air & $59.14 \%$ \\
\hline 2. & Kadar senyawa yang larut dalam air & $17.89 \%$ \\
\hline \multirow[t]{7}{*}{3.} & Penentuan Fitokimia ekstrak etanol & \\
\hline & $-\quad$ Alkaloid & $(+)$ \\
\hline & Fenolik & $(+)$ \\
\hline & Flavonoid & $(+)$ \\
\hline & Triterpenoid & $(+)$ \\
\hline & Steroid & $(-)$ \\
\hline & saponin & $(+)$ \\
\hline 4. & Penentuan kadar fenol & $0.825 \% \mathrm{~b} / \mathrm{b}$ \\
\hline 5. & Penentuan kadar flavonoid & $0.556 \% \mathrm{~b} / \mathrm{b}$ \\
\hline \multirow[t]{3}{*}{6.} & Penentuan kadar logam & \\
\hline & $-\quad \mathrm{Pb}$ & $1.61 \mathrm{ppm}$ \\
\hline & $\mathrm{Cd}$ & $0.069 \mathrm{ppm}$ \\
\hline
\end{tabular}




\section{KESIMPULAN}

Uji in vivo dan in vitro terhadap ekstrak tanaman pegagan telah menunjukkan hasil yang sangat baik. Ekstrak etil asetat 17,5 $\mathrm{mg} / \mathrm{kg}$ BB dan butanol 228,8 $\mathrm{mg} / \mathrm{kg}$ BB pegagan dibuktikan mempunyai efek hepatoprotektor pada uji in vivo menggunakan mencit yang diinduksi oleh $\mathrm{CCl}_{4}$. Ekstrak etil asetat mampu menurunkan kadar enzim alanine aminotransferase (ALT) dan aspartate aminotransferase (AST) sebesar 56\% dan $44 \%$ berturut-turut, sementara ekstrak butanol mampu menurunkan kadar enzim AST sebesar $3 \%$.

Parameter non spesifik untuk ekstrak etanol pegagan telah memenuhi persyaratan Farmakope Herbal tahun 2008 yang meliputi; penentuan kadar susut pengeringan $\leq 10 \%$, kadar abu $\leq 16.6 \%$ dan cemaran mikroba negative. Demikian pula untuk parameter spesifik yang dilakukan untuk ekstrak etanol pegagan, telah memenuhi persyaratan Farmakope Herbal tahun 2008 yang meliputi; kadar senyawa yang larut dalam air $\geq 28.3 \%$, kadar senyawa yang larut dalam etanol $\geq 2.1$ $\%$. Untuk pengujian kadar kandungan kimia (fitokimia) yang dilakukan secara kualitatif, ekstrak etanol pegagan positif mengandung senyawa alkaloid, fenolik, flavonoid, triterpenoid dan saponin namun negatif untuk kandungan senyawa steroid.

Secara kuantitatif kandungan total fenol dalam ekstrak sebesar $0.825 \% \mathrm{~b} / \mathrm{b}$ sedangkan untuk kadar total flavonoid sebesar $0.556 \%$ $\mathrm{b} / \mathrm{b}$. Penentuan kandungan kadar logam berat, diujikan pada 2 jenis logam yaitu: $\mathrm{Pb}$ dan $\mathrm{Cd}$. Kandungan logam dalam ekstrak pegagan sebesar 1.61 ppm untuk logam $\mathrm{Pb}$ dan 0.069 ppm untuk logam Cd.

Dari semua hasil data karakteristik parameter spesifik dan non spesifik yang telah dilakukan terhadap ekstrak etanol pegagan menunjukkan bahwa ekstrak yang dibuat telah memenuhi persyaratan Farmakope Herbal tahun 2008, yang berarti ekstrak etanol pegagan yang dibuat telah memenuhi standar sebagai ekstrak terstandar.

\section{DAFTAR PUSTAKA}

1. www.depkes.go.id/hepatitis, diakses pada tanggal 15 januari 2013.

2. H.U. Lee, E.A. Bae, M.J. Han, N.J. Kim, D.H. Kim: Hepatoprotective effect of ginsenoside $\mathrm{Rb} 1$ and compound $\mathrm{K}$ on tertbutyl hydroperoxide-induced liver injury. Liver International, 25: 1069-1073 (2005).

3. S. Singh, M.B. Thomas, S.P. Singh, D.Bhowmik, Plants used in Hepatoprotective Remedies in Traditional Indian medicine, Indian Journal of Research in Pharmacy and Biotechnology (online).

4. D. Tedesco, C. Domeneghini, D. Sciannimanico, M. Tameni, S. Steidler, S. Galletti, Silymarin, A possible hepatoprotector in dairy cows: biochemical and histological observations. J Vet Med A Physiol Pathol Clin Med. Mar; 51(2):85-9 (2004)

5. E.M. Williamson, D.T. Okpoko dan F.J. Evans. Selection, "Preparation and Pharmacology Evaluation of Plant Material". Pharmacological Method in Phytotherapy Research, 1:155-167. John Willey and Sons, Chichester. (1998)

6. G.M.M. Rao, C.V.Rao, P. Pushpangadan, A. Shirwaikar. Hepatoprotective effects of rubiadin, a major constituent of Rubiacordifolia Linn. Journal of Ethnopharmacology. 103: 484-490. (2006)

7. M.R. Venukumar, M.S. Latha. Hepatoprotective effect of the methanol extract of Curligo orchioides in $\mathrm{CCl} 4$ treated male rats. Indian Journal of Pharmacology 34:269-275.(2002)

8. C.C. Lin, P.C. Huang. Antioxidant and hepatoprotective effects of Acanthopanaxsenticosus. Phytotheraphy Research 14 :489-494 (2000)

9. K. Heyne. "Tumbuhan Berguna Indonesia". Badan Penelitian dan Pengembangan Kehutanan. Departemen Kehutanan. II: 1082 (1987)

10. D. Iswari. 'Seri Pengalaman. Obat Tradisional Sembuhkan Mereka", Trubus (2002) 
11. H. Lullman, K. Mohr, A. Ziegler dan D. Bieger. Color Atlas of Pharmacology, Second edition, 2000.

12. H.H.J. Gerets, E. Hanon, M. Cornet, S. Dhalluin, O. Depelchin, M. Canning, F.A. Atienzar: Selection of cytotoxicity markers for the screening of new chemical entities in a pharmaceutical context: A preliminary study using a multiplexing approach. Toxicology in Vitro 23: 319-33. (2009)

13. Anonim. Pedoman Pengujian dan Pengembangan Fitofarmaka. Penapisan Farmakologi, Pengujian Fitokimia dan Pengujian Klinik. Pengembangan Pemanfaatan Obat Bahan Alam. 1993.

14. Y.O. Teselkin, I.V. Babankova, V.K. Kolhir, A.I. Baginskaya, N.A. Tjukavkina, Y.A. Kolesnik, I.A. Selivanova, A.A. Eichholz. Dihydroquercetin as a means of antioxidative defence in rats with tetrachloromethane hepatitis. Phytotheraphy Research 14: 160-162. (2000)

15. Sanmugapriya E, Venkataraman S. Studies on hepatoprotective and antioxidant actions of Strychnos potatorum Linn. Seeds on CCl4-induced acute hepatic injury in experimental rats. Journal of Ethnopharmacology 105(1-2) : 154-160 (2006). 